\title{
Intra-sexual variation in male reproduction in teleost fish: a comparative approach
}

\author{
Rui F. Oliveira*, Albert F.H. Ros, David M. Gonçalves \\ Unidade de Investigação em Eco-Etologia, Instituto Superior de Psicologia Aplicada, Rua Jardim do Tabaco34, 1149-041 Lisboa, Portugal
}

Received 6 March 2005; revised 16 May 2005; accepted 5 June 2005

Available online 20 July 2005

\begin{abstract}
The occurrence of intra-sexual variation in reproduction is a widespread phenomenon in teleosts. One such form of variation consists in the occurrence of alternative male types: males that invest resources in mate attraction and males that exploit the investment of the former males, by trying to sneak fertilizations during spawning. These alternative reproductive tactics can be classified according to their plasticity during the life span of the individuals (i.e., fixed vs. sequential vs. reversible). Furthermore, the differences between morphs within a given species may involve a set of different traits, including reproductive behavior, the differentiation of male morphological traits, and the patterns of gonad tissue allocation and the differentiation of gonadal accessory glands. In this paper, we review the available data on four species exhibiting different types of intra-sexual plasticity in reproduction that have been studied in our lab. The data on the proximate mechanisms, androgens and forebrain arginine-vasotocin (AVT), underlying these alternative tactics suggest that between-morph differences in androgen levels, especially in 11-ketotestosterone, are especially present in species where the alternative male types have evolved morphological traits that are tactic-specific (i.e., sexual polymorphisms) and that differences in AVT appear to be related to between-morph differences in the expression of courtship behavior. Therefore, this comparative approach leads us to propose that the different endocrine systems are involved in the differentiation of different sets of traits that make up alternative phenotypes, and that the differentiation of alternative tactics is not controlled by a single endocrine system (e.g., androgens).
\end{abstract}

(C) 2005 Elsevier Inc. All rights reserved.

Keywords: Sexual plasticity; Alternative reproductive tactics; Fish; Androgens; Testosterone; 11-ketotestosterone; Arginine vasotocin; Reproductive behavior

\section{Introduction}

Teleost fish exhibit the widest range of modes of reproduction among vertebrates (Breder and Rosen, 1966; Thresher, 1984). The diversity in reproductive patterns includes gonochoristic species, male-to-female sex changing species, female-to-male sex changing species, serial (i.e., male-to-female-to-male) sex-changing species (e.g., goby Trimma okinawae, Sunobe and Nakazono, 1993), simultaneous hermaphrodites (see Demski, 1987 for a review), and asexual reproduction in some parthenogenic species (e.g., the amazon molly Poecilia formosa, Schartl et al., 1995). The fertilization mode also varies among teleosts: while

\footnotetext{
* Corresponding author. Fax: +351218860954

E-mail address: ruiol@ispa.pt (R.F. Oliveira).
}

most species are external fertilizers, live-bearers also occur in phylogenetic independent lines (Goodwin et al., 2002). Mating systems can vary from monogamous, to polygamous to promiscuous species (Turner, 1993). Also, the patterns of parental care are the most diverse among vertebrates, with most species showing no care, to species with bi-parental, paternal, or maternal care (Sargent and Gross, 1993). The high variability in reproductive modes is also present within species, ranging from inter-population differences in mating systems, to the occurrence of alternative sexual phenotypes within the same sex (e.g., Taborsky, 1994). This wide variation in their modes of reproduction makes teleosts a group of election for the study of the proximate causes of sexual plasticity in vertebrates.

One widely studied case of phenotypic plasticity is the intra-sexual variation in male reproductive behavior in fish. Although intra-sexual plasticity in male reproduction is 
widespread among animals (Shuster and Wade, 2003), teleosts are by far the vertebrate taxon with the highest incidence of species with alternative reproductive phenotypes (140 species from 28 different families, Taborsky, 1998). Alternative reproductive tactics, that is the occurrence of discrete polymodal behavioral phenotypes within the same sex among the adults of a given species (Brockmann, 2001), have been one of the most studied cases of intra-sexual variation in reproduction among teleosts (Taborsky, 1994, 2001).

Alternative tactics can be classified according to the observed patterns of behavior as fixed or plastic, depending on the same tactic being used by the same individuals during their whole lifetime or on individuals switching the tactic during their life span. Further, within plastic tactics, two sub-categories can be distinguished: irreversible sequential patterns when individuals switch from one tactic to another at a particular moment in their lifetime, and reversible patterns when individuals can change back and forth between patterns (Moore, 1991; Moore et al., 1998; Brockmann, 2001; Fig. 1). Two alternative modes of reproduction can usually be found in species with male alternative reproductive tactics: a bourgeois and a parasitic tactic (Taborsky, 1997). Bourgeois males invest in resources to attract mates, such as the differentiation of morphological ornaments, the expression of courtship signals, and/or the defense of a breeding territory (Taborsky, 1994, 1997, 2001). On the other hand, parasitic males exploit the investment made by the bourgeois males to get access to mates, using female mimicry, sneaking behavior, or cooperation with bourgeois males in order to get access to the spawning area (Taborsky, 1994, 1997, 2001). These alternative tactics result in different traits being selected in the two male types, with traits related with mate attraction and monopolization being selected in bourgeois males, whereas traits that increase the probability of stealing fertilizations from bourgeois males prevailing in parasitic males. This disruptive selection acting on a set of phenotypic traits may result in the creation of phenotypic mosaics in which both male and female traits are expressed in the same individual (e.g., parasitic males that mimic female morphology and behavior). Therefore, the expression of male reproductive behavior and male secondary sex characters may become dissociated from the differentiation of functional male gonads. Since sexual differentiation in vertebrates usually involves the action of androgens that in a cascade of events promotes the masculinization of different target tissues in the males, alternative phenotypes offer the possibility for an insight into the proximate mechanisms involved in sexual differentiation and underlying reproductive behavior, as in the parasitic tactic gonadal maturation and spermatogenesis can be dissociated from the expression of behavioral and morphological male traits.

In this paper, we will review the recent advances in the study of intra-sexual variation in reproductive behavior of four model species studied in our lab that exhibit different degrees of phenotypic variation in their mode of reproduction, and we will subsequently use this information to suggest how the proximate mechanisms underlying this plasticity may have evolved.

\section{Study model 1: sneaker males in the peacock blenny, Salaria pavo (Blenniidae)}

The peacock blenny is a small intertidal fish occurring in the Mediterranean and adjacent Atlantic coasts (Zander, 1986). The species presents a strong sexual dimorphism

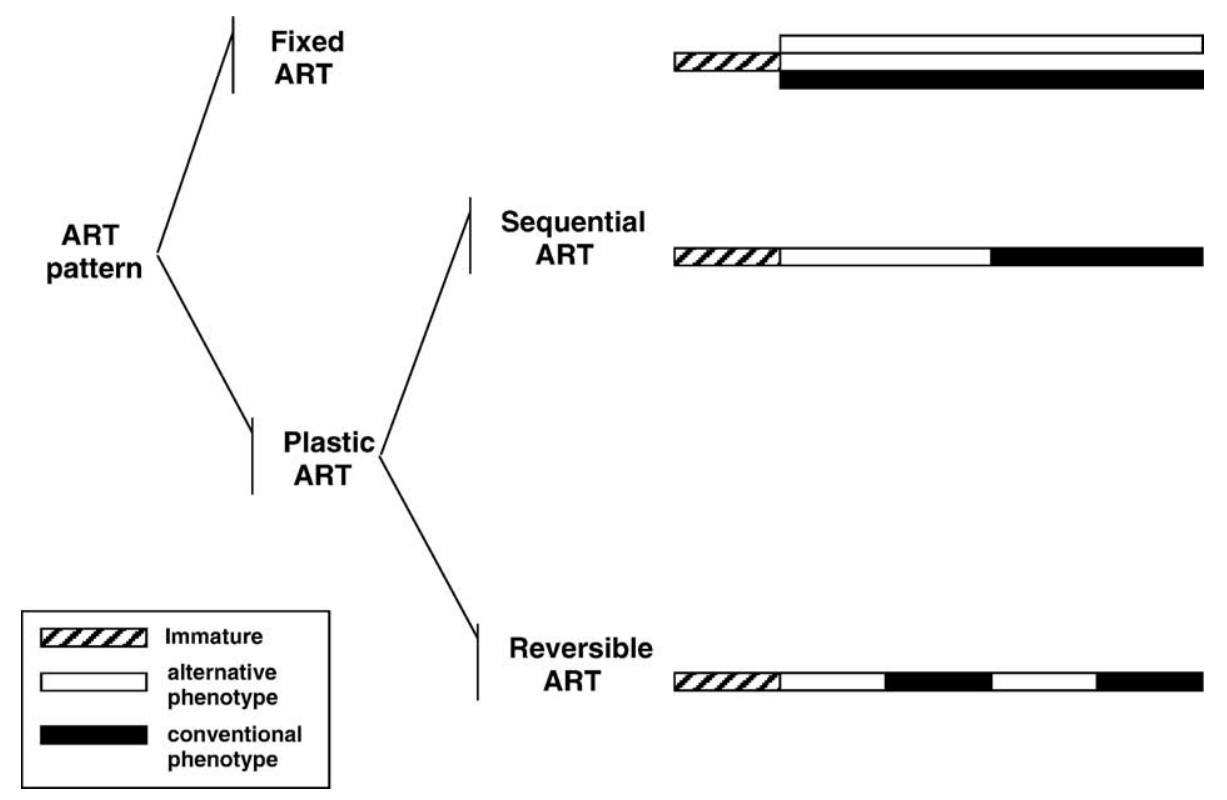

Fig. 1. Classification of alternative reproductive tactics based on observed patterns. 
with males being larger than females and presenting several conspicuous secondary sexual characters such as a head crest and an anal gland in the first two rays of the anal fin (Fishelson, 1963; Papaconstantinou, 1979; Patzner et al., 1986). Males defend nests in rock crevices or holes and take care of the eggs until they hatch (Patzner et al., 1986). Male alternative reproductive tactics have been described in two populations living in coastal lagoons (Gulf of Lion, France, Ruchon et al., 1995; and Ria Formosa, Portugal, Gonçalves et al., 1996), where a shortage and aggregation of nest sites seem to promote a strong male-male competition for nests and small males are unable to acquire nests. In the Portuguese population, small males reproduce by mimicking the females' courtship behavior and morphology in order to approach nesting males and sneak fertilizations of eggs during spawning events (Almada et al., 1994; Gonçalves et al., 1996). Sneaker males are younger than nesting males and have higher gonadosomatic indexes (GSI, Gonçalves et al., 1996). Within the small males' class, a bimodal distribution of the GSI occurs with smaller males presenting the highest values and larger males presenting the lowest values of all males (Gonçalves et al., 1996; Oliveira et al., 2001f). These data suggest a condition-dependent tactic for small males, which can either reproduce as sneakers or postpone reproduction to subsequent breeding seasons (immature males). The choice to reproduce or not in their first breeding season is likely to depend on body size as the efficiency of female mimicry may decrease as body size increases (Oliveira et al., 2001f). In fact, although sneakers are on average good female mimics to the eyes of nest-holders, sneakers receive more attacks and less courtship displays from nesting males as their body size increases (Gonçalves et al., 2005). In an ongoing mark-recapture study started in 2000 (with over 500 individuals marked so far), all sneakers and immature males marked in a given breeding season and recaptured in the following year had developed secondary sexual characters and many successfully defended a nest with eggs (T. Fagundes, D. Gonçalves, and R.F. Oliveira, unpublished data). No nesting males were ever observed switching to sneaker.

The proportion of sneakers in other populations where nest sites are abundant seems to be much lower (Gulf of Trieste, Adriatic Sea, Italy; J. Saraiva and R.F. Oliveira, unpublished data). Thus, the occurrence and proportion of the alternative phenotype is likely to be driven by ecological constraints. It has been proposed that ecological constraints modulate the social environment, and social cues may trigger a neuroendocrine cascade ultimately leading to tactic switching (Oliveira et al., 2001b). For example, in populations where nest sites are more abundant and less aggregated, male-male competition for nests is likely to be reduced and small males are predicted to receive fewer attacks from larger males. The effects of ecological conditions and social environment on tactic switching were tested in several experiments. In an experiment in which juvenile males were raised in environments with different nest-site availability regimes, the high-availability treatment promoted the development of nest-holder typical characters in smaller males. In this treatment, smaller males grew more, developed more the head crest and the testicular gland, and had a lower GSI when compared with smaller males from the low-availability treatment, which suggests that either ecological (low-nest availability) or social (strong male-male competition for nests) factors promote the development of the sneaker phenotype in smaller males. The fact that the larger juvenile males from each group did not respond to differences in nest availability further suggests that the adoption of the sneaker tactic is constrained by a body size threshold (R. Serrano, R.F. Oliveira, and E. Barata, unpublished data). In a second experiment, it was shown that social status also plays a role in tactic switching while density had no significant effect on the lifehistory decisions of immature males. However, dominant individuals within a group (either in low or high densities) developed more typical nest-holder-like characters such as the anal gland or the genital papilla and also grew more (T. Fagundes, M. Simões, and R.F. Oliveira, unpublished data). The results suggest that the outcome of won and lost social interactions influences the young male's decision to grow and become a nest-holder.

Thus, in S. pavo, male sexual plasticity conforms to a sequential alternative tactics with a large morphological differentiation which seem to be driven by ecological and/or social factors such as nest availability/male-male competition and the influence of these factors on the small males' reproductive decisions to be partially constrained by body size.

\section{Study model 2: satellite males in the Azorean rock-pool blenny, Parablennius parvicornis (Blenniidae)}

At the start of the reproductive season, males of the Azorean rock-pool blenny compete for nests in crevices in tide-pools (Santos, 1985). Fecund females visit these pools to lay their eggs, showing a preference for nests of bigger males (Santos and Barreiros, 1993; Oliveira et al., 2000). Nest-holding males are territorial and care for the eggs, and this double effort is reflected in a substantial decrease in body condition during the reproductive period (up to $30 \%$ of bodyweight, Santos et al., 1996). Some nest-holders give up brooding before the end of the reproductive season, and can be found as floaters in the tide-pools. Floaters are occasionally observed trying to take over established nests, suggesting low availability of high-quality nest sites (Santos and Barreiros, 1993). Most males (ca. 90\%) that have established themselves as nest-holders are larger than $12 \mathrm{~cm}$ of body length (3-7 years old, see Santos et al., 1995; smallest nest-holder male $=10 \mathrm{~cm}$, own observations). However, males mature after their first year when they are about $8 \mathrm{~cm}$. These smaller males of lower competitive ability have evolved alternative reproductive tactics in 
which they attempt to achieve parasitic fertilizations by acting as satellite males in nest-holders' territories (Santos and Almada, 1988). Satellite males help to defend the breeding territories and are tolerated by nest-holders, that is they receive relative low levels of aggression from the nestholding males and there is good evidence that the latter benefit from having satellites on their territories (Oliveira et al., 2002). Apart from the behavioral differences, males adopting different alternative tactics show a clear polymorphism (Santos, 1995): nest-holder and floater males have fully developed secondary sexual traits (M+ type) which are absent in sneaker and satellite males ( $\mathrm{M}-$ type). These traits include a longer and wider male-type genital papilla and the development of an anal gland that secretes a sex pheromone. As already documented above, the morphotypes differ in testis morphology. Testes are relatively bigger in $\mathrm{M}-$ males, while $\mathrm{M}+$ males have a testicular gland which is absent in the other morphotype. $\mathrm{M}-$ males have been observed to change to $\mathrm{M}+$ males from one year to the next (A.F.H. Ros, R.S. Santos, and R.F. Oliveira, unpublished data).

Summarizing, the alternative tactics in the rock-pool blenny are sequential and the ontogenetic "switch" between tactics comprises broad changes in reproductive behavior and morphology.

\section{Study model 3: pseudo-female behavior in the Mozambique tilapia, Oreochromis mossambicus (Cichlidae)}

The Mozambique tilapia is an African maternal mouthbrooding cichlid that displays a lek mating system. In this species, two major types of reproductive behavior patterns are present in the males. Territorial males establish breeding territories within dense nest aggregations in sandy or muddy bottoms, where they dig spawning pits, assume a dark coloration, defend a breeding territory, and actively court females (Neil, 1964). Spawning takes place in the pit and the female quickly takes eggs and sperm into her mouth where fertilization takes place. The embryos and fry are brooded in the female's mouth (Fryer and Iles, 1972; Bruton and Boltt, 1975). Sneaking males intrude into nests during a spawning episode and try to remain near the female exhibiting quivering behavior, which is usually an indicator of sperm release. Sneaking was predominantly performed by subordinate males, but even territorial males were occasionally observed to leave their territories to intrude into their neighbors' territories when spawning was occurring, and engaged in sneaking attempts (Oliveira and Almada, 1998a). Territorial males were also observed to court subordinate males displaying the full courtship sequence found in this species. Courted males performed the typical female sexual behavior, which includes following the courting male to the nest, assuming a pivot position in the nest while the other male circled them, and in fewer cases, putting their mouth close to the genital papillae of the courting male and performing chewing movements when the courting male releases sperm, which are typical of females inhaling sperm to ensure the fertilization of the eggs inside the mouth (Oliveira and Almada, 1998a).

Thus, in the Mozambique tilapia, sexual plasticity occurs as reversible alternative tactics with a quantitative (but not qualitative) morphological differentiation between the alternative phenotypes.

\section{Study model 4: monogamous vs. polygynous males in the St. Peter's fish, Sarotherodon galilaeus (Cichlidae)}

The St. Peter's fish $S$. galilaeus ranges from lake Kinneret and the Jordan in the Middle East to rivers and lakes throughout Africa (Trewavas, 1983). At the start of the breeding season, groups of $S$. galilaeus break up in pairs which search for a spawning site where they dig out a spawning pit (Fishelson, 1983). Pairs defend this site together until they spawn. Following spawning, both sexes may pick up eggs in their mouth to brood them in the buccal cavity, after which they leave the spawning site (Iles and Holden, 1969; Fishelson, 1983; Schwanck and Rana, 1991). Mouth brooding takes less than 2 weeks and both sexes engage in subsequent spawning events (Balshine-Earn, 1997). Both males and females take "decisions" after spawning which lead to a series of alternative reproductive tactics: (1) after spawning, both partners (bi-parental), or only one of the partners (uni-parental), pick up eggs to brood; (2) partners might stay together as a pair (monogamy) or might divorce and pair up later with another partner (polygamy). These "decisions", which are taken independently (Fishelson and Hilzerman, 2002), have important sexdependent consequences for the reproductive output of the individual (effects on body condition, inter-spawn interval, hatching success; Balshine-Earn, 1996; 1997).

In comparison with the courtship phase, spawning is a particular competitive and aggressive event. Just before spawning, males start to increase their aggression to any fish coming in the neighborhood of the spawning pit. This is important since intruders steal eggs and might even participate in spawning (A.F.H. Ros, personal observations). After eggs have been laid and fertilized, females harass the male until she takes eggs in her mouth (Schwanck and Rana, 1991). It has been suggested that the function of this female-male harassment is to incite the male to pick up eggs (Balshine-Earn and Earn, 1998). This may explain the observation that males with relatively large females have a higher propensity to pick up eggs for brooding than males with smaller females (Schwanck and Rana, 1991). We additionally showed that pairs that were better matched in size were more successful in spawning than less well matched pairs (Ros et al., 2003b). Thus, in this species, an association exists between a period of elevated aggression (during spawning) and the moment at which tactical 
'decisions' are made (to brood or not to brood; to divorce or not to divorce). From this, we expected that androgens, classically associated with aggressive behavior, should play a role in modulating alternative reproductive tactics in this species. Moreover, in birds, high androgen levels have been associated with the adoption of polygamy (Beletsky et al., 1995).

In summary, in the St. Peter's fish, the intra-sexual variation in male reproductive behavior consists in reversible alternative tactics without a morphological specialization.

\section{Neuroendocrine correlates of intra-sexual variation in reproduction}

Sex steroids and neuropeptides are two major potential endocrine candidates to be involved in the proximate mechanisms underlying the expression of alternative modes of reproduction. Sex steroids are involved in sexual differentiation and in the control of reproductive behavior in all vertebrate taxa, and neuropeptides are involved in the control of the reproductive axis (i.e., GnRH; White et al., 1995) and in the control of central pathways controlling the expression of reproductive behavior [e.g., arginine vasopressin (AVP) and arginine vasotocin (AVT); Goodson and Bass, 2001]. We have been investigating the involvement of androgens and AVT on the expression of intra-sexual variation in reproductive behavior in the four species studied.

\section{Androgens and intra-sexual variation in reproduction}

In the two blenniid species studied ( $S$. pavo and $P$. parvicornis), the gonads of alternative males (i.e., sneakers/ satellites) lack testicular glands which are gonadal accessory structures involved in sperm maturation and the main source of gonadal androgens in nest-holders (Reinboth and Becker, 1986; Lahnsteiner et al., 1990; Oliveira et al., 2001a). Accordingly, 11-ketotestosterone (KT) and testosterone (T) levels are lower in sneaker males than in nest-holders of $S$. pavo (Oliveira et al., 2001b), while only KT levels are higher in $\mathrm{M}+$ than in $\mathrm{M}-$ males of P. parvicornis (Oliveira et al., 2001c). In accordance with these data, alternative males (i.e., sneakers/satellites) that received silastic implants of KT and methyl-testosterone (MT) developed some of the typical nest-holder males' secondary sexual characters, such as the anal gland, both in S. pavo and in P. parvicornis (Oliveira et al., 2001d,e). Interestingly, in a subsequent experiment, $\mathrm{T}$ implants given to satellites of $P$. parvicornis had no effect on the expression of male characters (KT had the expected effect; A.F.H. Ros, C. Ferreira, R.F. Oliveira, and R.S. Santos, unpublished data). The difference in the effects of KT and MT vs. T may be explained by the fact that $\mathrm{T}$ can be aromatized peripherally which might prevent $\mathrm{T}$ from acting on androgen receptors in target tissues. Contrary to their effect on secondary sex characters, androgens had no effect on the allocation of gonadal tissue (i.e., GSI values; Oliveira et al., 2001d,e). The behavioral effects of the exogenous administration of androgens to the alternative morphs of S. pavo and P. parvicornis are also less clear. In the peacock blenny sneakers, the female-like courtship behavior was inhibited by KT, but the implants failed to elicit the male-like courtship behavior (Oliveira et al., 2001d). This suggests that either a longer time frame or other neuroendocrine or social triggers may be needed for a complete tactic switching in this species. In the rock-pool blenny, androgen-treated satellite males did not show a clear change towards the nest-holder type of behavior, and an unexpected decrease in aggressive behavior was found in KT-treated fish (Oliveira et al., 2001e). Contrastingly, nestholder males treated with KT increased the expression of aggressive behavior and concomitantly also increased the size of their breeding territories (Ros et al., 2004). In the field, despite the low KT levels in satellite males, both satellite and nest-holder males display aggressive behavior. However, the type of aggression varies in respect to some important aspects between satellites and nest-holders: satellites are actively aggressive towards other conspecifics but submissive to the nest-holder, while nest-holders are dominant and aggressive in response to any intruder close to the nest. Aggression in nest-holders is thus more routinelike than that of satellites which is in concordance with the observation in mice and tits that routine-like behavior is more common in individuals with high levels of androgens (either early in development or during challenges) than in individuals with low levels of these hormones (proactive vs. reactive coping style, Koolhaas et al., 1999; Kortea et al., 2005).

In O. mossambicus, dominant males that are successful in defending a breeding territory have higher levels of both $\mathrm{KT}$ and $\mathrm{T}$ than subordinate males that may adopt pseudofemale behavior and try sneaking fertilizations (Oliveira et al., 1996; Oliveira and Canário, 2001). Moreover, by measuring androgen levels before and after group formation, it has been shown that androgen levels prior to group formation were not good predictors of the social status that the individuals achieved when groups were formed, and that that social status modulates androgen levels (Oliveira et al., 1996). Therefore, in O. mossambicus, the association between different androgen profiles and alternative modes of reproduction is a result of a social modulation of androgens imposed by different social experiences imposed to territorial and subordinate males. These socially driven higher androgen levels in dominant males lead to a higher expression of male traits in these males. In fact, dominant males display a higher expression of both a set of morphological secondary sex characters and of male displaying behaviors (Oliveira and Almada, 1998b; Amorim and Almada, 2005), and this androgenization of dominant males seems to be mediated by androgens.

In $S$. galilaeus, the interaction between androgens, sexual stimulation, and reproductive tactics was investigated in an 
experiment in which groups varying in operational sex ratios were placed in large ponds (i.e., female biased, balanced, male biased; 4 replicas of each group, Ros et al., 2003a). There were no differences in KT and $\mathrm{T}$ levels between males that deserted the partner after spawning and repaired with another female (polygynous) and males that stayed with the partner after this event (monogamous) (Ros et al., 2003a). By comparing the behavior of males from different ponds we found that divorce initiated by the male was most abundant in female biased groups, whereas divorce initiated by the female tended to be more abundant in the male biased groups (Ros et al., 2003a). Androgen levels, however, were highest in the male biased groups, and highly correlated with the amount of received aggression but not with their own aggressive behavior. Therefore, tactical decisions in the reproductive context in S. galilaeus might depend on factors like partner availability and pair quality (see Ros et al., 2003b), and have emancipated from mechanisms controlled by sex steroids. For example, males in female biased group received relative high levels of sexual behavior, and this might have been a cue for the males to adjust their behavior towards a more polygamous tactic (Ros et al., 2003a). In a second experiment, paired males were offered the access to a novel female and partner preference was measured as the relative amount of time the male spent with its partner (vs. time spent with the novel female). A significant negative correlation between androgens (KT and T) and partner preference was found, suggesting that the more polygamous males had higher androgen levels (Oliveira et al., 2001g). In a third experiment, we tested the causality of this association between higher androgen levels and polygamy in males, by increasing androgen levels experimentally (intraperitoneal silastic implants filled with MT in oil or oil alone) in paired males and testing the males in the same choice test (Oliveira et al., 2001g). Androgen treatment did not affect the preference score significantly, which suggests that the higher levels of androgens in polygynous males is a result of their exposure to the novel female and not a cause for them to spend more time interacting with the novel female (Oliveira et al., 2001g).

A first review of the available data on androgen levels in species with ART was given in Brantley et al. (1993). These authors found that bourgeois males have significantly higher levels of circulating KT levels than parasitic males, and that there was no clear pattern regarding a difference in $\mathrm{T}$ levels between the two morphs. The species surveyed $(n=6)$ were not closely related to each other, and thus phylogenetical bias is most probably not present in this qualitative survey. A re-analysis of the currently available data (on 16 species from 9 different teleost families) yields similar results: there is a strong association between the alternative reproductive tactics and KT levels, but not with T (Oliveira, in press). Thus, the androgen patterns described above for the species studied by our lab partially agree with most other species with ART investigated so far.
In terms of the effects of androgen manipulations on the expression of alternative reproductive tactics, there is only one other species that has been studied apart from those described above: the plainfin midshipman Porichthys notatus (Lee and Bass, 2004). In this species, type I (i.e., bourgeois) males produce humming vocalizations during the breeding season in order to attract females to their nests, while type II (i.e., parasitic) males are silent and try to sneak fertilizations in type I males' nests during spawning (Brantley and Bass, 1994). These alternative tactics are fixed for life (Bass et al., 1996). Type II males that received an intraperitoneal silastic implant of KT neither show an increase in the size of the brain sonic motor nucleus, that controls the courtship calls typical of this morph, nor expressed the type I male territorial or courtship behaviors. Nevertheless, this treatment increased the sonic muscle mass and the frequency of sneaking behavior in type II males (Lee and Bass, 2004).

Taken together, these results suggest that irrespective of the alternative tactic type (i.e., fixed vs. sequential vs. reversible), androgens are more efficient in differentiating morphological than behavioral reproductive traits.

\section{AVT and intra-sexual variation in reproduction}

The hypothalamic neuropeptide AVP in mammals, or its homologue AVT in non-mammalian vertebrates, influences the expression of social behaviors in a wide range of vertebrates (Goodson and Bass, 2001). Exogenous administration of these neuropeptides induces the expression of different types of reproductive behaviors across all vertebrate taxa (Goodson and Bass, 2001), including the male spawning reflex and courtship behavior in fish (Pickford and Strecker, 1977; Bastian et al., 2001; Semsar et al., 2001; Salek et al., 2002; Carneiro et al., 2003). Species with intrasexual variation in reproductive behavior offer the possibility of investigating how AVT may be involved in the differential expression of behavior between male types. In all species studied so far, an association has been found between the expression of alternative tactics and forebrain AVT (i.e., soma size, number of AVT-ir neurons or AVT mRNA expression on a per cell basis, Grober and Bass, 1991; Foran and Bass, 1998; Grober, 1998; Godwin et al., 2000; for a review, see Foran and Bass, 1999).

In the peacock blenny, in which sex-role reversal occurs in courtship behavior (i.e., females and sneaker males are the major courting phenotypes, Almada et al., 1995), and thus the expression of courtship behavior is decoupled from the bourgeois tactic, AVT mRNA expression on a per cell basis (using in situ hybridization) is higher in both females and sneaker males than in nest-holders, suggesting that mRNA levels are correlated with the expression of courtship behavior rather than with the alternative morph (in fact, there are no differences in AVT-ir cell size or numbers between the two morphs; see Grober et al., 2002). Finally, no differences were found between alternative male morphs 
in the rock-pool blenny both on the absolute size and number of AVT-ir cells in the POA (Miranda et al., 2003). Interestingly, in this species, the parasitic morph consists in satellite males that help the nest-holder males in the defense of the breeding territory and to some extent in female attraction (Santos, 1985; Oliveira et al., 2002), and thus the behavioral differentiation between morphs is smaller in this species than in the other studied species. Therefore, the reported differences in the AVT-POA system between alternative sexual morphs are clearly associated with the expression of 'morph' typical behavior.

Of the four model species that we study, the effects of the exogenous manipulation of AVT levels have only been tested in the peacock blenny. In this species, AVT treatment of sneaker males increased the time spent in female nuptial coloration and the frequency of the female-like courtship behavior displayed towards nest-holder males. Conversely, sneakers treated with AVT and presented with a gravid female failed to express male courtship behavior (Carneiro et al., 2003). Accordingly, AVT induced the expression of both nuptial coloration and courtship behavior in females, but failed to promote any expression of male courtship behavior in nest-holders (Carneiro et al., 2003). As already mentioned above, KT treatment of sneaker males in this species inhibited the expression of female courtship behavior in sneaker males, but had no effect neither in the number nor in the soma size of AVT-POA neurons (Oliveira et al., 2001d), suggesting that the inhibitory effect of KT on AVT-dependent female-like courtship behavior is probably regulated by changes in mRNA expression. This hypothesis remains to be tested, but is supported by studies on other vertebrates species that present sex differences and/ or seasonal variation in AVP brain elements. This plasticity in AVP-POA neurons is regulated by $\mathrm{T}$ or by one of its metabolites (E2, DHT) acting on AVP mRNA expression and not on AVP-ir (Goodson and Bass, 2001 and references therein).

\section{General conclusions and prospects for future research}

With the four models discussed above, we hope to have illustrated the diversity of mechanisms that may underlie phenomena that is classified under the same label from a functional perspective. Moreover, the relative importance of different physiological mechanisms for the differentiation of tactic-specific traits might vary among behavioral, morphological, and gonadal traits and therefore the classic (i.e., mammalian) paradigm of androgens controlling the expression of the whole set of reproductive characters that characterize each tactic may be questioned (see Fig. 2). Androgens, and $11 \mathrm{KT}$ in particular, have proven to be very efficient in eliciting the expression of bourgeois male tacticspecific morphological traits while their effects on the expression of tactic-specific behavior was less clear. On the other hand, the data on the peacock blenny strongly suggest

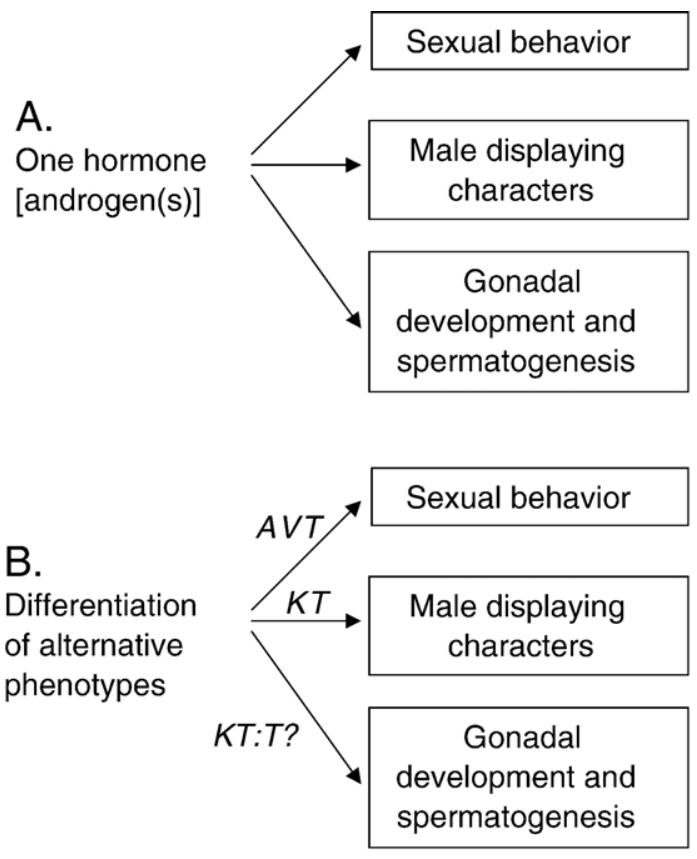

Fig. 2. Hypothesis to explain the proximate mechanisms underlying the expression of alternative reproductive tactics: (A) classic view according to which androgens play a major role in the differentiation of alternative phenotypes by acting pleiotropically on the whole set of tactic-specific characters; (B) proposed alternative view according to which the differentiation of alternative phenotypes depends on a set of proximate mechanisms acting in synergy to promote the differentiation of tacticspecific characters, which allows for the uncoupling of these characters in some cases.

an involvement of forebrain AVT pathways in the activation of courtship behavior (see text above; Fig. 2). Therefore, it is possible that the constellation of traits that make up the alternative phenotype may not all depend on the same gent (hormone). Indeed, the decoupling of different male traits in parasitic males may be achieved by other mechanisms apart from differences in hormone levels, namely, by varying the local micro-environments in the different target tissues, due to differential expression of receptors or to differential levels of activity of catabolic enzymes that modulate the availability of the active hormone to specific targets (e.g., 11- $\beta$ hydroxilase and $11-\beta-\mathrm{HSD}$, that metabolize $\mathrm{T}$ into $\mathrm{KT}$, are key steps in the expression of male secondary sex characters, spermatogenesis, and the modulation of the expression of reproductive behavior in male teleosts; Borg, 1994). This focus on target tissues when studying the mechanisms of intra-sexual variation in reproduction has rarely been used. One of the rare examples of such approach is a study on the relative levels of brain steroid receptors between alternative reproductive phenotypes in the protogynous wrasse, Halichoeres trimaculatus, where it was found, using competitive RT-PCR, that the levels of AR transcripts were significantly higher in the brain of terminal phase males than in initial phase males (Kim et al., 2002). No other significant differences in gene expression were observed either for AR in the gonads or for ER both in the 
brain and in the gonads. Thus, by varying the expression of AR in specific tissues (brain vs. gonad), bourgeois males (in this case terminal phase males) can both increase their sensitivity to circulating androgen levels in specific targets (the brain), and at the same time allow a compartmentalization of the effects of androgens, so that the potential deleterious effects of androgens can be avoided by varying AR densities in different tissues (Ketterson and Nolan, 1999). This mechanism hypothetically makes it possible to activate the expression of an androgen-dependent reproductive behavior in bourgeois males without having the associated costs of increasing spermatogenesis or the expression of a sex character, since the androgen action can be independently modulated at each compartment (brain vs. gonad vs. morphological secondary sex character). Studies focusing on target tissues are thus a major avenue for future research in this area. This is in our view the major lesson that we, as well as other areas of behavioral endocrinology, can take from comparative studies in Pisces.

\section{Acknowledgments}

We would like to thank all the colleagues that over the years have worked with us in the different projects on the challenging world of fish sexuality, in particular Vitor Almada, Adelino Canário, Matthew Grober, Emanuel Gonçalves, and Ricardo Serrão Santos, with whom various discussions over the years have helped to shape the current view we have of these phenomena. The writing of the current manuscript has been funded by the research grant (POCTI/BSE/38395/2001) funded by Fundação para a Ciência e a Tecnologia (Portugal) and the EU Program FEDER.

\section{References}

Almada, V.C., Gonçalves, E.J., Oliveira, R.F., Santos, A.J., 1995. Courting females: ecological constraints affect sex roles in a natural population of the blenniid fish Salaria pavo. Anim. Behav. 49, 1125-1127.

Amorim, M.P.C., Almada, V.C., 2005. The outcome of male-male encounter affects subsequent sound production during courtship in the cichlid fish Oreochromis mossambicus. Anim. Behav. 69, 595-601.

Balshine-Earn, S., 1996. Reproductive rates, operational sex ratios and mate choice in St. Peter's fish. Behav. Ecol. Sociobiol. 39, 107-116.

Balshine-Earn, S., 1997. The benefits of uniparental versus biparental mouth brooding in Galilee St. Peter's fish. J. Fish Biol. 50, 371-381.

Balshine-Earn, S., Earn, D.J.D., 1998. On the evolutionary pathway of parental care in mouth-brooding cichlid fish. Proc. R. Soc. London, Ser. B Biol. Sci. 256, 2217-2222.

Bass, A.H., Horvath, B.J., Brothers, E.B., 1996. Nonsequential developmental trajectories lead to dimorphic vocal circuitry for males with alternative reproductive tactics. J. Neurobiol. 30, 493-504.

Bastian, J., Schniederjan, S., Nguyenkim, J., 2001. Arginine vasotocin modulates a sexually dimorphic communication behavior in the weakly electric fish Apteronotus leptorhynchus. J. Exp. Biol. 204, 1909-1923.

Beletsky, L.D., Gori, D.F., Freeman, S., Wingfield, J.C., 1995. Testosterone and polygyny in birds. In: Power, D.M. (Ed.), Curr. Ornithol., vol. 10. Plenum Press, New York, pp. 1-41.

Borg, B., 1994. Androgens in teleost fishes. Comp. Biochem. Physiol., C 109, 219-245.

Brantley, R.K., Bass, A.H., 1994. Alternative male spawning tactics and acoustic signals in the plainfin midshipman fish, Porichthys notatus (Teleostei, Batrachoididae). Ethology 96, 213-232.

Brantley, R.K., Wingfield, J.C., Bass, A.H., 1993. Sex steroid levels in Porichthys notatus, a fish with alternative reproductive tactics, and a review of the hormonal bases for male dimorphism among teleost fishes. Horm. Behav. 27, 332-347.

Breder, C.M., Rosen, D.E., 1966. Modes of Reproduction in Fishes. Natural History Press, New York

Brockmann, H.J., 2001. The evolution of alternative strategies and tactics. Adv. Study Behav. 30, 1-51.

Bruton, M.N., Boltt, R.E., 1975. Aspects of the biology of Tilapia mossambica Peters (Pisces: Cichlidae) in a natural freshwater lake (Lake Sibaya, South Africa). J. Fish Biol. 7, 423-446.

Carneiro, L.A., Oliveira, R.F., Canário, A.V.M., Grober, M.S., 2003. The effect of arginine vasotocin on courtship behaviour in a blenniid fish with alternative reproductive tactics. Fish Physiol. Biochem. 28, $241-243$.

Fishelson, L., 1963. Observations on littoral fishes of Israel: I. Behaviour of Blennius pavo Risso (Teleostei, Blenniidae). J. Zool. 12, 67-80.

Fishelson, L., 1983. Social behavior of adult tilapia fish in captivity (Israel). In: Fishelson, L., Yaron, Z. (Eds.), Proceedings of the International Symposium on Tilapia in Aquaculture. Tel Aviv Univ. Press, Tel Aviv, pp. $48-58$.

Fishelson, L., Hilzerman, F., 2002. Flexibility in reproductive styles of male St. Peter's tilapia, Sarotherodon galilaeus (Cichlidae). Environ. Biol. Fishes 63, 173-182.

Foran, C.M., Bass, A.H., 1998. Preoptic AVT immunoreactive neurons of a teleost fish with alternative reproductive tactics. Gen. Comp. Endocrinol. 111, 271-282.

Foran, C.M., Bass, A.H., 1999. Preoptic GnRH and AVT: axes for sexual plasticity in teleost fish. Gen. Comp. Endocrinol. 116, 141-152.

Fryer, G., Iles, T.D., 1972. The Cichlid Fishes of the Great Lakes of Africa-Their Biology and Evolution. Oliver and Boyd, Edinburgh.

Godwin, J., Sawby, R., Warner, R.R., Crews, D., Grober, M.S., 2000. Hypothalamic arginine vasotocin mRNA abundance variation across sexes and with sex change in a coral reef fish. Brain Behav. Evol. 55, $77-84$.

Gonçalves, D., Matos, R., Fagundes, T., Oliveira, R.F., 2005. Bourgeois males of the peacock blenny, Salaria pavo, discriminate female mimics from females? Ethology 111, 559-772.

Gonçalves, E.J., Almada, V.C., Oliveira, R.F., Santos, A.J., 1996. Female mimicry as a mating tactic in males of the blenniid fish Salaria pavo. J. Mar. Biol. Assoc. U. K. 76, 529-538.

Goodson, J., Bass, A.H., 2001. Social behaviour functions and related anatomical characteristics of vasotocin/vasopressin systems in vertebrates. Brain Res. Rev. 35, 246-265.

Goodwin, N.B., Dulvy, N.K., Reynolds, J.D., 2002. Life history correlates in the evolution of live-bearing in fishes. Philos. Trans. R. Soc., B 357, $259-267$.

Grober, M.S., 1998. Socially controlled sex change: integrating ultimate and proximate levels of analysis. Acta Ethol. 1, 3-17.

Grober, M.S., Bass, A.H., 1991. Neuronal correlates of sex/role change in labrid fishes: LHRH-like immunoreactivity. Brain Behav. Evol. 38, $302-312$

Grober, M.S., George, A.A., Watkins, K.K., Carneiro, L.A., Oliveira, R.F., 2002. Forebrain AVT and courtship in a fish with alternative reproductive tactics. Brain Res. Bull. 57, 23-25.

Iles, T.D., Holden, M.J., 1969. Bi-parental mouth brooding in Tilapia galilaea (Pisces, Cichlidae). J. Zool. (London) 158, 327-333.

Ketterson, E.D., Nolan Jr., V., 1999. Adaptation, exaptation, and constraint: a hormonal perspective. Am. Nat. 154, S4-S25.

Kim, S.J., Ogasawara, K., Park, J.G., Takemura, A., Nakamura, M., 2002. 
Sequence and expression of androgen receptor and estrogen receptor gene in the sex types of protogynous wrasse, Heliochoeres trimaculatus. Gen. Comp. Endocrinol. 127, 165-173.

Koolhaas, J.M., Korte, S.M., De Boer, S.F., Van Der Vegt, B.J., Van Reenen, C.G., Hopster, H., De Jong, I.C., Ruis, M.A., Blokhuis, H.J., 1999. Coping styles in animals: current status in behavior and stressphysiology. Neurosci. Biobehav. Rev. 23, 925-935.

Kortea, S.M., Koolhaas, J.M., Wingfield, J.C., McEwen, B.S., 2005. The Darwinian concept of stress: benefits of allostasis and costs of allostatic load and the trade-offs in health and disease. Neurosci. Biobehav. Rev. $29,3-38$.

Lahnsteiner, F., Lametschwandtner, A., Patzner, R.A., 1990. The secondary blood vessel system of segmental arteries and dorsal aorta in Blennius pavo and Zosterisessor ophiocephalus. Histology, fine structure and SEM of vascular corrosion casts. Scanning Microsc. 4, 111-124.

Lee, J.S.F., Bass, A.H., 2004. Effects of 11-ketotestosterone on brain, sonic muscle, and behavior in type-II midshipman fish. Horm. Behav. 46, $115-116$

Miranda, J.A., Oliveira, R.F., Carneiro, L.A., Santos, R.S., Grober, M.S., 2003. Neurochemical correlates of male polymorphism and alternative reproductive tactics in the Azorean rock-pool blenny, Parablennius parvicornis. Gen. Comp. Endocrinol. 132, 183-189.

Moore, M.C., 1991. Application of organization-activation theory to alternative male reproductive strategies: a review. Horm. Behav. 25, $154-179$.

Moore, M.C., Hews, D.K., Knapp, R., 1998. Hormonal control and evolution of alternative male phenotypes: generalizations of models for sexual differentiation. Am. Zool. 38, 133-151.

Neil, E.H., 1964. An analysis of colour changes and social behaviour of Tilapia mossambica. Univ. Calif. Publ. Zool. 75, 1-58.

Oliveira, R.F., in press. Neuroendocrine mechanisms of alternative reproductive tactics in fish. In: Sloman, K.A., Wilson R.W., Balshine, S. (Guest Editors; W.S. Hoar, D.J. Randall and A.P. Farrell, Series editors), Fish Physiology, vol. 24-Behaviour: Interactions with Physiology. Elsevier, New York.

Oliveira, R.F., Almada, V.C., 1998a. Mating tactics and male-male courtship in the lek-breeding cichlid Oreochromis mossambicus. J. Fish Biol. 52, 1115-1129.

Oliveira, R.F., Almada, V.C., 1998b. Androgenization of dominant males in a cichlid fish: androgens mediate the social modulation of sexually dimorphic traits. Ethology 104, 841-858.

Oliveira, R.F., Canário, A.V.M., 2001. Hormones and social behavior of cichlid fishes: a case study in the Mozambique tilapia. J. Aquaricult. Aquat. Sci. 9, 187-207.

Oliveira, R.F., Almada, V.C., Canario, A.V.M., 1996. Social modulation of sex steroid concentrations in the urine of male cichlid fish Oreochromis mossambicus. Horm. Behav. 30, 2-12.

Oliveira, R.F., Miranda, J.A., Carvalho, N., Gonçalves, E.J., Grober, M.S., Santos, R.S., 2000. Male mating success in the Azorean rock-pool blenny: the effects of body size, male behaviour and nest characteristics. J. Fish Biol. 57, 1416-1428.

Oliveira, R.F., Almada, V.C., Gonçalves, E.J., Forsgren, E., Canario, A.V.M., 2001a. Androgen levels and social interactions in breeding males of the peacock blenny. J. Fish Biol. 58, 897-908.

Oliveira, R.F., Canario, A.V.M., Grober, M.S., 2001b. Male sexual polymorphism, alternative reproductive tactics and androgens in combtooth blennies (Pisces: Blenniidae). Horm. Behav. 40, 266-275.

Oliveira, R.F., Canario, A.V.M., Grober, M.S., Santos, R.S., 2001c. Endocrine correlates of alternative reproductive tactics and male polymorphism in the Azorean rock-pool blenny, Parablennius sanguinolentus parvicornis. Gen. Comp. Endocrinol. 121, 278-288.

Oliveira, R.F., Carneiro, L.A., Gonçalves, D.M., Canario, A.V.M., Grober, M.S., 2001d. 11-Ketotestosterone inhibits the alternative mating tactic in sneaker males of the peacock blenny, Salaria pavo. Brain Behav. Evol. 58, 28-37.

Oliveira, R.F., Carneiro, L.A., Canario, A.V.M., Grober, M.S., 2001e. Effects of androgens on social behaviour and morphology of alternative reproductive males of the Azorean rock-pool blenny. Horm. Behav. 39, $157-166$.

Oliveira, R.F., Gonçalves, E.J., Santos, R.S., 2001f. Gonadal investment of young males in two blenniid fishes with alternative mating tactics. J. Fish Biol. 59, 459-462.

Oliveira, R.F., Ros, A.F.H., Hirschenhauser, K., Canario, A.V.M., 2001g. Androgens and mating systems in fish: intra- and interspecific analyses. In: Goos, H.J., Rastogi, R.K., Vaudry, H., Pierantoni, R. (Eds.), Perspectives in Comparative Endocrinology: Unity and Diversity. Monduzzi Editore, Bologna, pp. 203-215.

Oliveira, R.F., Miranda, J.A., Carvalho, N., Gonçalves, E.J., Grober, M.S., Santos, R.S., 2002. The relationship between the presence of satellite males and nest-holders' mating success in the Azorean rockpool blenny, Parablennius sanguinolentus parvicornis. Ethology 108, $223-235$.

Papaconstantinou, C.A., 1979. Secondary sex characters of blennioid fishes (Pisces: Blenniidae). Thalassografica 1, 57-75.

Patzner, R.A., Seiwald, M., Adlgasser, M., Kaurin, G., 1986. The reproduction of Blennius pavo: V. Reproductive behaviour in natural environment. Zool. Anz. 216, 338-350.

Pickford, G.E., Strecker, E.L., 1977. The spawning reflex response of the killifish Fundulus heteroclitus; isotocin is relatively inactive in comparison with arginine vasotocin. Gen. Comp. Endocrinol. 32, $132-137$.

Reinboth, R., Becker, B., 1986. In vitro studies on steroid metabolism by gonadal tissues from ambisexual teleosts: I. Conversion of 14-C testosterone by males and females of the protogynous wrasse Coris julis L. Gen. Comp. Endocrinol. 55, 245-250.

Ros, A.F.H., Canario, A.V., Couto, E., Zeilstra, I., Oliveira, R.F., 2003a. Endocrine correlates of intra-specific variation in the mating system of the St. Peter's fish (Sarotherodon galilaeus). Horm. Behav. 44, $365-373$.

Ros, A.F.H., Zeilstra, I., Oliveira, R.F., 2003b. Mate choice in the Galilee St. Peter's fish, Sarotherodon galilaeus. Behaviour 140, 1173-1188.

Ros, A.F.H., Bruintjes, R., Santos, R.S., Canario, A.V.M., Oliveira, R.F., 2004. The role of androgens in the trade-off between territorial and parental behavior in the Azorean rock-pool blenny, Parablennius parvicornis. Horm. Behav. 46, 491-497.

Ruchon, F., Laugier, T., Quignard, J.P., 1995. Alternative male reproductive strategies in the peacock blenny. J. Fish Biol. 47, 826-840.

Salek, S.J., Sullivan, C.V., Godwin, J., 2002. Arginine vasotocin effects on courtship behavior in male white perch (Morone americana). Behav. Brain Res. 133, 177-183.

Santos, R.S., 1985. Parentais e satélites: tácticas alternativas de acasalamento nos machos de Blennius sanguinolentus Pallas (Pisces: Blenniidae). Arquipél., Sér. Ciênc. Nat. 6, 119-146.

Santos, R.S., 1995. Anatomy and histology of secondary sexual characters gonads and liver of the rock-pool blenny (Parablennius sanguinolentus parvicornis) (Piscus: Blenniidae) of the Azores, Arquipélago. Life Mar. Sci. 13A, 21-38.

Santos, R.S., Almada, V., 1988. Intraspecific variations in reproductive tactics in males of the rocky intertidal fish Blennius sanguinolentus in Azores. In: Chellazzi, G., Vannini, M. (Eds.), Behavioral Adaptation to Intertidal Life. Plenum Press, New York, pp. 421-447.

Santos, R.S., Barreiros, J.P., 1993. The ethogram of Parablennius sanguinolentus parvicornis (Pisces: Blenniidae) of the Azores, Arquipélago. Life Mar. Sci. 11A, 73-90.

Santos, R.S., Nash, R.D.M., Hawkins, S.J., 1995. Age, growth and sex ratio of the Azorean rock-pool blenny, Parablennius sanguinolentus parvicornis. J. Mar. Biol. Assoc. U. K. 75, 751-754.

Santos, R.S., Hawkins, S.J., Nash, R.D.M., 1996. Reproductive phenology of the Azorean rock pool blenny, a fish with alternative mating tactics. J. Fish Biol. 48, 842-858.

Sargent, R.C., Gross, M.R., 1993. William's principle: an explanation of parental care in teleost fishes. In: Pitcher, T.J. (Ed.), Behaviour of Teleost Fishes, 2nd ed. Chapman and Hall, London, pp. 333-361. Schartl, M., Wilde, B., Schlupp, I., Parzefall, J., 1995. Evolutionary origin 
of a parthenoform, the Amazon molly, Poecilia formosa, on the basis of a molecular genealogy. Evolution 49, 827-835.

Schwanck, E., Rana, K., 1991. Male-female parental roles in Sarotherodon galilaeus (Pisces: Cichlidae). Ethology 89, 229-243.

Semsar, K.A., Kandel, F.L.M., Godwin, J., 2001. Manipulations of the AVT system shift social status and related courtship and aggressive behavior in the bluehead wrasse. Horm. Behav. 40, 21-31.

Shuster, S.M., Wade, M.J., 2003. Mating Systems and Strategies. Princeton Univ. Press, Princeton.

Sunobe, T., Nakazono, A., 1993. Sex change in both directions by alteration of social dominance in Trimma okinawae (Pisces: Gobiidae). Ethology 94, 339-345

Taborsky, M., 1994. Sneakers, satellites, and helpers: parasitic and cooperative behavior in fish reproduction. Adv. Study Behav. 23, $1-100$.

Taborsky, M., 1997. Bourgeois and parasitic tactics: do we need collective, functional terms for alternative reproductive behaviours? Behav. Ecol. Sociobiol. 41, 361-362.
Taborsky, M., 1998. Sperm competition in fish: 'bourgeois' males and parasitic spawning. TREE 13, 222-227.

Taborsky, M., 2001. The evolution of bourgeois, parasitic, and cooperative reproductive behaviors in fishes. J. Hered. 92, 100-110.

Thresher, R.E., 1984. Reproduction in Reef Fishes. T.F.H. Publications, Neptune City.

Trewavas, E. (Ed.), 1983. Tilapiine Fishes of the Genera Sarotherodon, Oreochromis and Danakilia. British Mus. Nat. Hist., London.

Turner, G., 1993. Teleost mating behaviour. In: Pitcher, T.J. (Ed.), Behaviour of Teleost Fishes, 2nd ed. Chapman and Hall, London, pp. 307-331.

White, S.A., Kasten, T.L., Bond, C.T., Adelman, J.P., Fernald, R.D., 1995. Three gonadotropin-releasing hormone genes in one organism suggest novel roles for an ancient peptide. Proc. Natl. Acad. Sci. U. S. A. 92 $8363-8367$.

Zander, C.D., 1986. Blenniidae. In: Whithead, H., Bauchot, M.L., Hureau, J.C., Nielsen, J., Tortonese, E. (Eds.), Fishes of the North-eastern Atlantic and the Mediterranean. Unesco, Paris, pp. 1096-1112. 